\title{
An Assessment of Spatial Variations of Some Soil Properties under Different Land Uses in South-Western Nigeria
}

\author{
B. A. Senjobi ${ }^{1 *}$, S. J. Akinsete ${ }^{2}$, O. T. Ande ${ }^{3}$, C. T. Senjobi ${ }^{4}$, M. Aluku ${ }^{5}$ \\ and O. A. Ogunkunle ${ }^{6}$ \\ ${ }^{1}$ Federal University of Agriculture, Abeokuta, Ogun State, Nigeria. \\ ${ }^{2}$ Federal University of Agriculture, Abeokuta, Ogun State, Nigeria \\ ${ }^{3}$ Institute of Agricultural Research and Training, Moor Plantation, Ibadan, Nigeria. \\ ${ }^{4}$ Tai Solarin College of Education, Omu-ljebu, Ogun State, Nigeria. \\ ${ }^{5}$ Department of Crop Production, Olabisi Onabanjo University, Ago-Iwoye, \\ Ogun State, Nigeria. \\ ${ }^{6}$ Department of Agronomy, University of Ibadan, Ibadan, Nigeria.
}

Authors' contributions

The research was carried out by author MA under the supervision of author BAS. All the other authors assisted in the write up, statistical analysis, proof reading and final editing of the work.

Research Article

Received $5^{\text {th }}$ March 2013

Accepted $26^{\text {th }}$ June 2013

Published 24 ${ }^{\text {th }}$ July 2013

\section{ABSTRACT}

Land use and soil management affect the distribution of soil properties thereby resulting in changes in the fertility status. Soil physical and chemical properties on the surface (0-30 $\mathrm{cm}$ ) of five land uses (cassava/maize, oil palm, cowpea, secondary forest and building site) on a sandy loam Alfisol (Typic paleudalf) were assessed for spatial variations. All the land uses differed significantly $(\mathrm{P}<0.01)$ from each other in at least three properties. Cassava/maize intercrop and secondary forest differed in thirteen properties; cassava/maize and oil palm in seven and cassava/maize and cowpea in five indicating differential removal variability among land use types. In terms of number of soil properties with high variability ( $C V>35 \%$ ), the order was cassava/maize (1), oil palm (2), building site (5) > secondary forest (4) > cowpea (3). The study established that different land uses influence the soil differently within the same soil class. Therefore, this must be taken into 
consideration in order to reduce soil fertility decline and enhance proper soil management. There must therefore, be a careful choice of appropriate use of land if we are to optimise production since loss of soil and fertility status may be difficult to replace in one's lifetime.

Keywords: Land use; fertility decline; food insecurity; choice of land use.

\section{INTRODUCTION}

It is widely known that land use types influence soil properties differently [1]. However, the extent to which land use types influence soil properties need to be studied to greater details. This is because soil varies with land uses from location to location [2]. The spatial variation in soil properties with land use types could not be over emphasised since it is an important aspect in soil fertility decline studies. This is also necessary because spatial variation in soil properties has not received the same amount of research attention as soil erosion, possibly because soil fertility decline is less visible, less spectacular, and more difficult to assess. Although, few studies had been conducted on soil spatial variation as reported by $[3,4]$ and [5], yet the increasing rate of soil degradation owing to inappropriate land usage calls for more attention especially on land use studies. There is therefore need to know the extent to which soil properties vary under different land uses, so as to provide better understanding for effective soil fertility management and contribute significantly to the careful choice of appropriate land use. This is the premise upon which this study is based with the aim of assessing the differences in soil properties resulting from the different agricultural land use types.

\section{MATERIALS AND METHODS}

The study was carried out at the Olabisi Onabanjo University, Ago-Iwoye, which is located in the rainforest belt of south-western Nigeria. Ago-Iwoye is located between the latitude $3^{0} 45^{\prime}$ and $4^{\circ} 05^{\prime} \mathrm{E}$. The area is associated with long rainy season, March to October with peaks between June and July and September and October. The mean annual rainfall is $1350 \mathrm{~mm}$ with about $80 \%$ of it being concentrated within the months of April and October. Mean relative humidity of the area is generally high $(80 \%)$ with the peak between May and October. The mean temperature of the area is $29^{\circ} \mathrm{C}$ and this low range accounts for its constantly high temperature. The mean annual sunshine hours recorded for the area is 2000 and the mean net radiation for the study is $70 \mathrm{~kg} / \mathrm{cm}$ (Ikenne Meteorogical Station). The soil is generally sandy especially at the top horizons. The soils are highly deficient in mineral reserves due to the high intensity of weathering and leaching of the soil. The clay content is of the kaoline type with low water and nutrient holding capacities [6], while the cation exchange capacity (CEC) ranges from as low as $1.3 \mathrm{cmol} / \mathrm{kg}$ to $17.3 \mathrm{cmol} / \mathrm{kg}$ in the top soil. The values of the exchangeable cations are generally low which is due to their susceptibility to leaching as a result of heavy rainfall and sandy nature of the soils. The $\mathrm{pH}$ of the area also decreases with depth [6].

Five land use types occurring on the same soil type within a distance of 30-60 m were studied. These include:

1. Cassava/Maize Cropping (CM): The land was under fallow for a period of 7 years before conversion to arable production. Mechanized method of clearing is often practiced in this site. 
2. Oil palm (OP): This was a 20 years old oil palm production at the time of study. This was basically established for commercial purposes, with minimal soil management practices.

3. Cowpea (CO): This site was cultivated on the adjacement plot of the arable crops (CM). This site has been under the cultivation of arable crops for a period of seven years, prior to cultivation with cowpea.

4. Under Brushed Secondary Forest (FO): This land use consists of big trees, shrubs, climbers and smaller weeds. The under story is opened and the soil surface is covered by a thick litter layer of dead leaves and twigs. This forest has been in existence since the inception of the University in 1982. It was used as a control to serve as undisturbed soil.

5. $\quad$ Building Site (BS): The bush regrowth around WAPCO building site in the main campus of the University was used because of its potential for backyard farming and was opened for construction purposes in recent times from secondary forest. Tree species found in the study area include Pentaclethra macrophylla, Basqueria angloansis, Guarea spp., Mimusop spp., Cola gigantean, and there is a wide spread of Elaeis guineensis and these were dominated by the presence of Chlomolaena odorata, a perennial weed found in fallow lands in south western Nigeria.

Using a systematic sampling procedure, composite samplings were taken with the aid of soil auger at the surface $(0-15 \mathrm{~cm})$ and sub-surface $(15-30 \mathrm{~cm})$ depths from both the long standing forest region which was chosen to serve as the control and the other four land-use types. The samples were then air dried, crushed and sieved for chemical and physical analyses in the laboratory.

The soil particles size analyses were determined using the hydrometer method [7] with sodium hexametaphosphate as the dispersing agent. Soil $\mathrm{pH}$ was determined potentiometrically in both water and $0.01 \mathrm{M}$ potassium chloride solution (1:1). Exchangeable bases were extracted with neutral ammonium acetate solution; [8] $\mathrm{Ca}$ and $\mathrm{Mg}$ were determined by atomic absorption spectrophotometry, and $\mathrm{K}$ and $\mathrm{Na}$ by flame photometry. Exchangeable acidity was determined by the $\mathrm{KCl}$ extraction method [9], total nitrogen was determined by the macro-kjeldahl digestion method of [8], available phosphorus was determined by the [10] method. Organic carbon was determined by the method of [11]. ECEC was determined as the sum of exchangeable bases and exchangeable acidity. Available micronutrients were determined by Atomic Absorption Spectrophotometer (AAS) method after leaching with $\mathrm{NH}_{4} \mathrm{Cl}$ [12].

The data were subjected to analysis of variance (ANOVA) and means were separated using least significant difference (LSD). Co-efficient of variation (CV\%) by [13] was used for grouping of soil properties.

\section{RESULTS AND DISCUSSION}

From the data in Table 1, the cowpea plot (CO) was significantly $(p=0.05)$ more fertile than other land use types. It contains more exchangeable bases and organic carbon and is similar to other land uses in other properties. The presence of higher value of organic carbon could be attributed to both the fallow land that has just been opened up and the conserving nature of cover crops like cowpea which does not only fix atmospheric nitrogen, but prevent the removal of top soil and organic residue from the soil through any agent of degradation such as erosion. There was more extractable potassium as well as nitrogen in secondary 
forest (FO) than any of the other land use types. This was probably because of the longer period of their accumulation than any other land use where erosion due to soil exposure as well as the cultivation of soil depleting crops like maize and cassava had limited their accumulation. The sandy texture of the soils, particularly in the oil palm (OP) resulted in the excessive drainage and low moisture thereby leading to the leaching of essential nutrients especially potassium which is needed for high yield in oil palm production, as reported by $[14,7,15]$. It is interesting to discover that cassava/maize cropping system which was planted on the same plot with cowpea after the opening up of the fallow and showed decline in soil fertility as reflected in Table 1 compared with other land use types. This was because of the depleting nature of such crops as far as nutrients are concerned, coupled with the exposure of land to erosion which ultimately washes away the fertility and fragile topsoil.

Table 1. Mean Value of Soil Properties under Different Land Uses

\begin{tabular}{llllll}
\hline $\begin{array}{l}\text { Soil } \\
\text { Properties }\end{array}$ & $\begin{array}{l}\text { Cassava/ } \\
\text { Maize } \\
\text { Cropping }\end{array}$ & $\begin{array}{l}\text { Oil Palm } \\
\text { Plantation }\end{array}$ & $\begin{array}{l}\text { Building } \\
\text { Site }\end{array}$ & $\begin{array}{l}\text { Cowpea } \\
\text { Plot }\end{array}$ & $\begin{array}{l}\text { Secondary } \\
\text { Forest }\end{array}$ \\
\hline $\mathrm{pH}$ & $6.1 \pm 0.12$ & $6.1 \pm 0.15$ & $6.3 \pm 0.17$ & $6.5 \pm 0.19$ & $6.5 \pm 0.14$ \\
$\%$ Sand & $82.5 \pm 4.68$ & $90.2 \pm 4.69$ & $83.0 \pm 6.28$ & $80.5 \pm 5.61$ & $86.2 \pm 5.18$ \\
$\%$ Silt & $14.5 \pm 4.68$ & $7.9 \pm 5.43$ & $12.9 \pm 5.47$ & $15.2 \pm 4.34$ & $10.5 \pm 4.27$ \\
$\%$ Clay & $2.91 \pm 1.51$ & $1.9 \pm 1.03$ & $3.3 \pm 2.07$ & $4.3 \pm 1.51$ & $3.3 \pm 2.07$ \\
$\mathrm{Ca}(\mathrm{cmol} / \mathrm{Kg})$ & $1.0 \pm 0.24$ & $1.5 \pm 0.35$ & $1.3 \pm 0.59$ & $1.3 \pm 0.59$ & $1.0 \pm 0.33$ \\
$\mathrm{Mg}(\mathrm{cmol} / \mathrm{Kg})$ & $1.0 \pm 0.63$ & $0.9 \pm 0.11$ & $2.2 \pm 0.35$ & $2.3 \pm 0.80$ & $1.4 \pm 0.38$ \\
$\mathrm{~K}(\mathrm{cmol} / \mathrm{Kg})$ & $0.2 \pm 0.09$ & $0.1 \pm 0.02$ & $0.2 \pm 0.06$ & $0.2 \pm 0.11$ & $0.4 \pm 0.38$ \\
$\mathrm{Na}(\mathrm{cmol} / \mathrm{Kg})$ & $1.2 \pm 0.80$ & $1.4 \pm 0.71$ & $1.9 \pm 0.88$ & $0.7 \pm 0.07$ & $0.7 \pm 0.06$ \\
$\mathrm{H}+$ & $0.1 \pm 0.01$ & $0.1 \pm 0.01$ & $0.1 \pm 0.01$ & $0.1 \pm 0.01$ & $0.1 \pm 0.01$ \\
$\mathrm{CEC}$ & $3.5 \pm 1.54$ & $4.0 \pm 0.89$ & $5.4 \pm 1.16$ & $4.7 \pm 0.95$ & $3.6 \pm 0.90$ \\
$\% \mathrm{BS}$ & $96.7 \pm 1.00$ & $97.4 \pm 0.69$ & $98.3 \pm 0.43$ & $98.1 \pm 0.54$ & $97.7 \pm 0.067$ \\
$\% \mathrm{C}$ & $0.4 \pm 0.24$ & $0.5 \pm 0.14$ & $0.6 \pm 0.23$ & $0.8 \pm 0.25$ & $0.20 \pm 0.028$ \\
$\% \mathrm{~N}$ & $0.04 \pm 0.01$ & $0.1 \pm 0.01$ & $0.1 \pm 0-034$ & $0.2 \pm 0.025$ & $0.2 \pm 0.028$ \\
$\mathrm{Av} . \mathrm{P}(\mathrm{Mg} / \mathrm{Kg})$ & $3.1 \pm 1.29$ & $7.3 \pm 3.26$ & $8.3 \pm 4.30$ & $10.9 \pm 4.13$ & $12.9 \pm 4.22$ \\
$\mathrm{Zn}(\mathrm{Mg} / \mathrm{Kg})$ & $4.34+2.14$ & $4.4 \pm 2.37$ & $4.1 \pm 1.37$ & $4.6 \pm 1.29$ & $5.2 \pm 1.22$ \\
\hline
\end{tabular}

It is important to note that inappropriate allocation of land for any use hinders the optimization of agricultural productivity as could be seen around the building site which showed high fertility status compared with cassava/maize based cropping system and oil palm. This therefore calls for the appropriate use of the land for the purpose it is best suited for as reported by [2].

Table 2 shows that the differences among land uses were statistically significant for 9 of the 15 soil properties considered. The differences in silt, clay, calcium, carbon, nitrogen and $\mathrm{Zn}$ were not significant. 
Table 2. Analysis of Variance of the Soil Properties

\begin{tabular}{|c|c|c|c|c|}
\hline \multirow[t]{2}{*}{ Property } & \multicolumn{2}{|c|}{ Mean Square } & \multirow[t]{2}{*}{$\mathbf{F}$} & \multirow[t]{2}{*}{ Significance } \\
\hline & Trt (Land Use Type) & Error & & \\
\hline $\mathrm{pH}$ & 0.18235 & 0.0251 & 7.26494 & NS \\
\hline$\%$ Sand & 82.86667 & 28.32 & 2.926083 & * \\
\hline$\%$ Silt & 42.16 & 25.28 & 1.667722 & NS \\
\hline$\%$ Clay & 4.2 & 2.826667 & 1.485849 & NS \\
\hline $\mathrm{Ca}(\mathrm{cmol} / \mathrm{Kg})$ & 0.277706 & 0.162928 & 1.704471 & NS \\
\hline $\mathrm{Mg}(\mathrm{cmol} / \mathrm{Kg})$ & 2.525763 & 0.263179 & 9.597143 & $* * *$ \\
\hline $\mathrm{K}(\mathrm{cmol} / \mathrm{Kg})$ & 0.051606 & 0.040748 & 1.266467 & * \\
\hline $\mathrm{Na}(\mathrm{cmol} / \mathrm{Kg})$ & 1.86779 & 0.260702 & 7.164464 & $\star \star \star *$ \\
\hline $\mathrm{H}+$ & 0.000463 & 6.93E-05 & 6.682692 & $* * *$ \\
\hline CEC & 5.799506 & 0.833226 & 6.960304 & *** \\
\hline$\% \mathrm{BS}$ & 2.224903 & 0.478723 & 4.647577 & *** \\
\hline$\% \mathrm{C}$ & 0.11543 & 0.042084 & 2.742848 & NS \\
\hline$\% \mathrm{~N}$ & 0.04778 & 0.029215 & 1.635386 & NS \\
\hline Av.P $(\mathrm{Mg} / \mathrm{Kg})$ & 84.37365 & 11.9394 & 7.066825 & $\star \star * *$ \\
\hline $\mathrm{Zn}(\mathrm{Mg} / \mathrm{Kg})$ & 1.029167 & 3.045 & 0.337986 & NS \\
\hline
\end{tabular}

The results of the L.S.D. tests (Table 3a) are summarized in Table 3b. The cassava/maize land use differs from the secondary forest in all thirteen properties, from the oil palm in seven properties, from cowpeas land use in five properties and from building site in four properties. The least different pair differs in at least three soil properties. The cassava/maize land use is different from all the other land use types in $\mathrm{P}$, oil palm is different from others in $\mathrm{pH}, \mathrm{K} \mathrm{H}^{+}$, CEC, $\mathrm{C}$ and $\mathrm{N}$. The cowpeas land use from others in silt, clay, $\mathrm{Mg}, \mathrm{K}, \mathrm{H}^{+}, \mathrm{CEC}, \mathrm{C}$ and $\mathrm{N}$. However, there is no property distinguishing the building site from the others. The changes in soil properties resulting from different land uses or plant species are large, though it is difficult to explain some of these results. If for future uses some of the land uses need to be merged with little or no fertility decline, they can be grouped rationally according to the number of significantly different properties. From Table $3 \mathrm{~b}$, it can be seen that the land uses that can be combined with least fertility decline are building sites and cowpeas, cassava/maize crops and building site, cassava/maize crops and cowpeas. At the other extreme is the cassava/maize and secondary forest pair with more than twelve properties significantly different, merging these two types is not advisable because of the high degree of variability. The result emphasised the need for caution in assuming uniformity of soil properties between areas previously or currently used for different crop combinations of land uses, even if they occur on the same soil type, because land uses influence soil properties differently consequently leading to various degree of fertility decline. 
Table 3a. Significant differences $(F<0.05)$ in Soil Properties between Land Uses

\begin{tabular}{|c|c|c|c|c|c|}
\hline \multirow[t]{2}{*}{ Property } & \multicolumn{5}{|c|}{ Significance of the differences between land uses + } \\
\hline & $\mathbf{C M}$ & OP & BS & CO & FO \\
\hline $\mathrm{pH}$ & $\mathrm{d}$ & $\mathrm{cd}$ & de & $\mathrm{e}$ & $\mathrm{e}$ \\
\hline$\%$ Sand & b & b & b & b & b \\
\hline$\%$ Silt & $\mathrm{C}$ & $\mathrm{C}$ & c & $\mathrm{c}$ & $\mathrm{d}$ \\
\hline$\%$ Clay & ef & ef & $f$ & ef & $\mathrm{fg}$ \\
\hline $\mathrm{Ca}(\mathrm{cmol} / \mathrm{Kg})$ & f & $f$ & $\mathrm{~g}$ & $\mathrm{~g}$ & $\mathrm{gh}$ \\
\hline $\mathrm{Mg}(\mathrm{cmol} / \mathrm{Kg})$ & $\mathrm{fg}$ & $f$ & $f$ & $\mathrm{fg}$ & $\mathrm{g}$ \\
\hline $\mathrm{K}(\mathrm{cmol} / \mathrm{Kg})$ & $g$ & $f$ & $g$ & $g$ & $\mathrm{~h}$ \\
\hline $\mathrm{Na}(\mathrm{cmol} / \mathrm{Kg})$ & $\mathrm{f}$ & $f$ & $\mathrm{fg}$ & $\mathrm{g}$ & $\mathrm{h}$ \\
\hline $\mathrm{H}+$ & $g$ & $g$ & $g$ & $\mathrm{~g}$ & $\mathrm{~h}$ \\
\hline CEC & $\mathrm{e}$ & de & $\mathrm{e}$ & $\mathrm{e}$ & $f$ \\
\hline$\% B S$ & a & $\mathrm{a}$ & $\mathrm{a}$ & a & $\mathrm{a}$ \\
\hline$\% \mathrm{C}$ & $\mathrm{g}$ & f & $\mathrm{g}$ & $\mathrm{g}$ & $\mathrm{h}$ \\
\hline$\% \mathrm{~N}$ & $\mathrm{~g}$ & f & $\mathrm{g}$ & $\mathrm{g}$ & $\mathrm{h}$ \\
\hline Av.P $(\mathrm{Mg} / \mathrm{Kg})$ & $\mathrm{e}$ & c & d & d & c \\
\hline $\mathrm{Zn}(\mathrm{Mg} / \mathrm{Kg})$ & de & d & ef & e & ef \\
\hline
\end{tabular}

Table 3b. Summary of LSD Tests: Number and Properties Significant differences Between Land Use Pairs

\begin{tabular}{lll}
\hline Land Use Pair & No. of Properties & Soil Properties \\
\hline CM - OP & 7 & pH, K, H+, CEC, C, N, P \\
CM - BS & 4 & Clay, Ca, P, Zn \\
CM - CO & 5 & pH, Ca, Na, P, Zn \\
CM - FO & 13 & pH, Silt, Clay, Ca, Mg, K, N, H+, CEC, C, N, P, Zn \\
OP - BS & 10 & pH, Clay, Ca, Mg, K, H+, CEC, C, N, P, Zn \\
OP - CO & 10 & pH, Ca, K, Na, H+, CEC, C, N, P, Zn \\
OP - FO & 11 & pH, Silt, Clay, Ca, Mg, K, Na, H+, CEC, C, N, Zn \\
BS - CO & 3 & pH, Clay, Na \\
BS - FO & 10 & pH, Silt, Mg, K, Na, H+, CEC, C, N, P \\
CO - FO & 10 & Silt, Clay, Mg, K, Na, H+, CEC, C, N, P \\
\hline
\end{tabular}

Grouping of soil properties by co-efficient of variation (C.V.\%) [18] showed that cowpeas land use was more homogenous than the others (Table 4). The soil properties (exchangeable $\mathrm{Ca}, \mathrm{K}$, and $\mathrm{P}$ ) were highly variable (group III) in the cowpeas land use, but 48 properties were highly variable in other land use types. This suggests that cultivating the land to cowpea will not only improve the soil fertility (i.e. degrade the land less), but also decrease soil variability and this is desirable for both practical and experimental agriculture, since it does not expose the land to any agent of degradation. 
Table 4. Significant differences $(F<0.05)$ in Soil Properties Between Land Uses

\begin{tabular}{|c|c|c|c|c|c|}
\hline \multirow[t]{2}{*}{ Soil Properties } & \multicolumn{5}{|c|}{ CV Group in Land Use Type } \\
\hline & CM & OP & BS & CO & FO \\
\hline $\mathrm{pH}$ & 1 & I & $\mathrm{I}$ & $\mathrm{I}$ & $\mathrm{I}$ \\
\hline$\%$ Sand & I & I & I & I & I \\
\hline$\%$ Silt & II & III $(69 \%$ I) & III & II & III \\
\hline$\%$ Clay & III & III & III $(63 \%$ I) & II & III \\
\hline $\mathrm{Ca}(\mathrm{cmol} / \mathrm{Kg})$ & II & II & II & III & II \\
\hline $\mathrm{Mg}(\mathrm{cmol} / \mathrm{Kg})$ & III & 1 & II & II & II \\
\hline $\mathrm{K}(\mathrm{cmol} / \mathrm{Kg})$ & III & II & II & III (55\%I) & III (95\%l) \\
\hline $\mathrm{Na}(\mathrm{cmol} / \mathrm{Kg})$ & III (67\%l) & III & III & I & I \\
\hline $\mathrm{H}_{+}$ & 1 & 1 & 1 & I & I \\
\hline CEC & III & II & II & II & II \\
\hline$\% \mathrm{BS}$ & 1 & I & I & i & i \\
\hline$\% \mathrm{C}$ & III & II & III & II & III \\
\hline$\% \mathrm{~N}$ & II & I & II & II & II \\
\hline Av.P $(\mathrm{Mg} / \mathrm{Kg})$ & III & III & III & III & III \\
\hline $\mathrm{Zn}(\mathrm{Mg} / \mathrm{Kg})$ & III & III & II & II & I \\
\hline
\end{tabular}

\section{CONCLUSION}

It was glaring from the results obtained that changes in relevant soil properties emanated from different land uses. Thus it is erroneous to assume that soils from the same mapping unit or type will exhibit uniformity in physical and chemical properties even after been subjected to different land uses. In view of the above, it then becomes necessary to give consideration to the variations in soil properties due to different land uses particularly when two plots under different land use are to be combined for a new use, selected for sampling for soil testing programs or in allocation for field experiment. This is necessary in order to reduce soil fertility decline associated with wrong usage of land which has great implication on sustainable agricultural practices. Therefore, there must be a careful choice of appropriate use of the land since loss of soil fertility status may be difficult to replace in one's lifetime. This will go a long way to meet the food and fibre needs of ever-increasing growing population thereby combating food insecurity at large.

\section{COMPETING INTERESTS}

Authors have declared that no competing interests exist.

\section{REFERENCES}

1. Senjobi BA, Ogunkunle OA. Effect of land use on soil degradation and soil productivity decline on alfisols and Ultisols in south western Nigeria. Journal of Agriculturae Conspectus Scientificus, Faculty of Agriculture, University of Zagreb, Crotia, 2010;75(1):9-19.

2. Senjobi BA, Ogunkunle OA. Effect of different land use types and their implications on land degradation and productivity in Ogun State, Nigeria. Journal of Agricultural Biotechnology and Sustainable Development. 2011;3(1):7-18. 
3. Adejuwon JO, Ekanade O. The physical components of soil renewal under bush fallow in a tropical environment. Geo-Eco-trap. 1986;10:57-70.

4. Adejuwon JO, Ekanade O. A comparison of soil properties under different land use types in a part of the Nigerian Cocoa Belt. CATENA (Braunschweig). 1988;15:319331.

5. Ekanade O. An assessment of the temporal variations of soil properties under cocoa (Theobroma cacao L.) and fallow towards increasing cocoa production in Nigeria. Soil Technology, Cremlingen. 1989;2:171-184.

6. Senjobi BA, Ayoola AO, Ayanlaja SA. Evaluation of OSU soils for tree and arable crops production. The Ogun Journal of Agricultural sciences. 2001;1:214-224.

7. Bouyoucous $\mathrm{GH}$. A recalibration of the Hydrometer method for making mechanical analysis. Agronomy Journal. 1951;43:434-438.

8. Jackson ML. Soil chemical analysis. Prentice Hall, New York; 1962.

9. Mclean EO. Aluminium: In methods of soil analysis (Ed. C.A. Black). Agronomy No. 9, Part 2. Amer. Soc. Agronomy. Madison, Wisconsin. 1965;978-98.

10. Bray RH, Kurtz LT. Determination of total organic and available forms of phosphorus in soils. Soil Science. 1945;59:22-229.

11. Walkley A, Black IA. Determination of organic matter in the soil. Soil Science. 1934;37:549-556.

12. Senjobi BA. Parametric and conventional approaches for soil potential evaluation in three ecological zones of southern Nigeria. Moor Journal of Agricultural Research, $2001 ; 2(2):$ 91-102.

13. Wilding LP, Dress LL. Spatial variability: a pedologists viewpoint. In: Diversity of soils in the tropics. ASA. Special Publications. 1978;34:1-12.

14. Tinker PBH. Changes occurring in the sedimentary soils for southern Nigeria after oil palm plantation establishment. Journal of the West African Institute for Oil Palm Research. 1963;4:66-81.

15. Ogunkunle OA. Soil in land suitability evaluation. An example with oil palm in Nigeria. Soil use and management. 1993:9:35-40.

(c) 2013 Senjobi et al.; This is an Open Access article distributed under the terms of the Creative Commons Attribution License (http://creativecommons.org/licenses/by/3.0), which permits unrestricted use, distribution, and reproduction in any medium, provided the original work is properly cited.

Peer-review history:

The peer review history for this paper can be accessed here: http://www.sciencedomain.org/review-history.php?iid=236\&id=2\&aid=1727 